\title{
CONSIDERATIONS IN THE SELECTION OF MODEL SUBSTRATES FOR MICROBIOLOGICAL EFFECTS RESEARCH
}

\author{
A.J. Francis and A.W. Rose*
}

*Department ol Geosciences

Penneylysnia State Universily

University Park, PA 16802

January 1984

torice

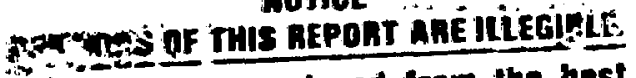
* mes busu reprotucest from the best matlable coor to permit the brandeft. iuss|ble arailability.

\section{TERRESTRIAL AND NĢUATIC ECOLOGY DIVISIOH}

DEPARTMENT OF APPLIED SCIENCE

BROOKHAYEN MATIONAL LABORATORY

ASSOCIATED UMIVERSITIES, INC.

UMDER COKCRACT NO. OE-ACO2-76CHODO16 WITH THE

UNITED STATES DEPARTMENT OF ERERGY 


\section{DISCLAMER}

Thie report wae prepared an an account of work sponeored by an agency of the Unjted States Government. Neither the Uniled States Govemment nor any agency thereof. nor any of their employee, nor any of their contractors, oubcontractors. or their employees, makes any worranty, expres or implied, or tseumes any !egal ii bility or repponoibility for the accuracy, completenew, of yoefulness of any information. upparatue, product, $D^{-}$, proceses dieclosed, or trepresents : $r_{i}$, it use would not infringe privately owned rights. Reference herein to any upecific commercial prod yct, procese. or ervice by trade name, trademark, manufacturer, or otherwiet, dives not necessarily conotitute or imply its endnnement, recommendation, orfavoring by the United States Government or any azency, contractor or :ubcontractor thereot. The views and opinione of autbors expresed herein do not necesurily oute or reflect thowe of the United Stales Government or any agency, con tractor or eubcon tracter thereof.

Printed in the United States of America Available from

Natinnal Technical Information Service

J.S. Department of Commerce

5285 Port Royal Rond

Springfield, VA 22161

NTIS price coden:

Printed Copy: A03; Microfiche Copy: A01 


\section{PREEACE}

The purpose of this paper is to select a representarive or a codel substrate for basic research on anaerobic microblological transfcration and transport of chemlcal substances (e.g., trace metals) in subsurface environwents. This research is part of the "Subsurface Transport Progran" in which geochemical, hydrologlcal and blologlcal cycling of energy residuals in subsurface environients are belng studied (Wobber, 1983). Th1s research 18 stonsored by the Ecological Res'tarch Diviston, Offlce of Health and Environmental Research, Department of Energy. Th1s work1ng paper was prepared at the request of Dr. Frank J. Wobber of the Department of Energy and is a result of the Geochemical and Blochemical Working Group meeting wich tet at Brookhaven National Laboratory (BNL), August 1983.

\section{DISCLAIMER}

This report was prepared as an scoount of work sponsored by an apercy of tse United State Government. Neither the United State Gowernment nor any erency thereof, nor any of their employeen, makes any warreaty, expres or implied, or anumes eny legel libility or responsibility for the accuracy, compietensw, or velulnew of any informetion, spparatue, projuct, or process discloed, or represents that its une would not infringe privalely owsed rights. Reference hetein to any specific commercill product, procem, of servioe by trade name, trademart, manufacturet, of otberwive does not necesurily constitule or inply its endornement, room. mendation, or favoring by the United States Government of any apency thereof. The views and opinions of autbers expremed herein do not necematily state or rellect thone of the Unitad Suten Gowernment or any ayency thereof. 


\section{ABSTRACT}

The physical and chemical characteristics of several energy residues have been briefly reviewed in order to select a model or representative substrate of basic research to determine the signiflcance of anaerobic microblal dissolution and wobilization or lmobilization of toxic trace elements under subsurface environental conditions. The wajor factors wich influence the issolution and mobilization of trace metals have been critically examined, e.g., (1) effects on plf of leachates (pyrite oxtdation), soluble ac1d, and basic compounds; (11) effects on oxidation state of leachates (oridation state of Fe, presence of organics); (111) concentration of toxic inorganic species, and chemiral form; ( $1 v$ ) surface area of waste particles; and (v) physical strength and particle size, with resuliting effects on permeability of the substrate. Several major physical and chentcul characteristics are common to energy-related residues yet each of these raterials has a unique set of physical and chemical properties. The pros and cons of selecting a single model substrate for microblological research were discussed at the Geochemical and Blochemlcal Working Group Meeting and use of the end-member concept was suggested. From the abundance, distribution, forms of trace metals present, and volume of these metal-containing residues disposed of in the subsurface environments, microblological studies can be performed with coal beneficlation and coal gasiflcation residues under a variety of subsurface environmental conditions, and results can be validated in the field. The baslc sclentific information obtalned from this research can be applied to other materials of similar composition. 


\section{ACKNOWLEDGMENTS}

Valuable suggestions in the preparation of this document were provided by the menbers of the Geochemical and Blochenical Working group which wet at BNL In August 1983. We thank Dr. F.J. Wobber, OHER, Department of Energy; Dr. R. Turner, Dak Rldge Natlonal Laboratory; Dr. J. Rogers, Paciflc Northweat Laboratory; and Dr. P.J. Sullivan, Ball State University, Indiana, for their help. 
Preface................................................. 111

Abstract.............................................

Acknou ledgment........................................... 1

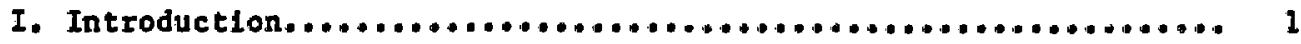

II. General Characteristics of Energy Residues..................... 2 Characteristics of Waste from Coal Wining and Coal Conversion. 2

Coal Preparation Waste................................... 4

Coal Combustion Waste........................................ 4

Coal Conversion Waste..................................... 5

jranium Mill Taflings.................................... 6

III. Important Characteristics of Model Substrate.................. 6

Major Element Concentration and pH of Aqueous Solution......... 7

Acid pH.............................................. 7

Alkaline pH........................................... B

Neutral pH........................................ 8

Oxidation State of Leachates................................... 9

Surface Properties of Particles in Substrate.................... 13

Abundance and Chemlcal-Mineraloglcal Form of Trace Elements... 14

Partlcle Size, Shape, and Strength........................... 14

IV. Selection of a Representative Substrate for Microblological

Research.............................................. 15

v. Summary ............................................ 23

VI. References............................................ 24 


\section{INTRODUCTION}

A major national concern in the terrestrial disposal of conplex mixtures of chenlcal substances is the contanination of ground and surface waters by leachate centaining trace wetals and organic compounds. Although much $1 \mathrm{~s}$ known about afcroblal transforation of chenical substances under aeroblc conditions, scientific information on the role of anaeroblc microbial processes in the mobilization and 1mobilization of toxic metals In subsurface environments is unavallable. Trace element behavior is affected in a najor way by bacteris, but little is known of the processes and mechanlams involved, In particular, of the range and nature of bacterial effects in environwents that are anoxic or transitional tetween oxygenated and anoxic. The Influence of environmental factors (pH, Eh, temperature, moisture) and the mechanisus involved in the microbial dissolution of toxic metals in anaeroblc or transitional environwents need further study, as does the Interaction of aerobic and anaerobic environments. The form of the trace wetal (elemental, oxide, or sulfide), the avallability or presence of nutrlents (carbon aind nitrogen source), and the presence of alternate electron acceptors ( $\mathrm{Fe}^{3+}, \mathrm{MnO}_{2}, \mathrm{NO}_{3}^{-}, \mathrm{SO}_{4}{ }^{2-}$, organic compounds) will affect microblal activity and microbial transformation of trace metals in subsurface environments.

Energy residuals contain a wide varlety of minerals in their natural state (coal beneficlation residues, will-tallings, etc.) or toxic trace metals converted to varlous other forms (elevental, oxldes, etc.), depending on the specific process employed (coal combustion, cosl conversion, nuclear, etc.). Conolderable amounts of these energy wastes are presently being produced at sites 11ke coal-cleanup plants and uranium mines, but with coal gasification, liquification and 011 shales processing the volume of wastes will be enormous and the consequences of their 1mproper disposal would be sevtza. Mf.croorganisms will play a major role in the dissolution and f1xation of toxic trace elements from energy regiduals disposed of in the terrestrial environment and mfcroblal mobilization of toxic metals could be critical, especially when these wastes are codisposed. The emphasis of this paper 1s, therefore, an Identification of the key characteristics of energy residuals that are relevant to microblal processes and the selection of a limited number of materials for experimentation. The basic results of experimentation should be applicable to a wide varlety of man-made and natural environments, lincluding energ.y residues.

The obfectives of this research are to determine (1) the abllity of microblal processes to mobilize and lmobilize toxic trace elements such as $A s, C d, C r, C u, ~ Z H g, ~ I n, ~ N 1, ~ S e, ~ P b$, and $\mathrm{Zn}$ under subsurface environmental conditions, (11) the biochemical wechanisms involved in the dissolution and mobilization of selected trace metals it anaerobic environments, (111) the environmental parameters affecting anaerobic microbial dissolution and mobiilzation of trace metals, and ( $1 v$ ) the effects of specific anaerobic microblal processes such as sulfate-reducing, denitrifying, iron-reducing, fermentative (blodegradation products and metabolites), and methanogenic conditions on dissolution of selected trace metals under anaerobic conditions. 
Inftially, experinents 111 be performed to provide optimal conditions for anaeroblc mferoblal growth (nutrient amendments, $\mathrm{pH}$, temperature, etc.) in order to show that trace metals frow a model substrate are being solubllized by anaeroblc microblal action. Subsequent laboratory experiments w111 address the effect of various environmental condit.ons (mutrients, pH, Eh, temperature, molsture) that exists in subsurface environments and determine the rate and extent of dissolution of selected metals.

Laboratory evaluation of the accelerated mathering and release of toxic constituents from energy residuals will be simplified if experiments can be performed on a representative substrate in great detall under a virlety of conditions. In order to carry out experiments under conditions more similar to natural environment:s, it is desirable to select one or more typical materials to serve as a substrate. The intent of this paper is to discuss the characteristics of such a material and the range of natural conditions under which experimentation might be relevant to obtaln basic sclentiflc information which can be applied to many types of ratural materials and man-made wastes.

\section{GENERAL CHARACTERISTICS OF ENERGY RESIDUES}

The wastes from coal mining, coal combustion, gasiflcation, and 11quefaction, as well as oll shale and uranium mining, are similar in that the major mineralogical components are derived from sedimentary rocks and minerals existing within or in proximity to the coal or other energy material. Accompanyling these 1norganic materials are residual coal and other organic reaction products.

\section{A. Characteristics of Waste frow Coal Mining and Coal Conversion}

The most abundant minerals in coal and its overburden are various types of clays (Ca-K-Na-Mg-Fe aluminosilicates), quartz $\left(\mathrm{SiO}_{2}\right), \mathrm{Ca}, \mathrm{Mg}$, and Fe carbonates, pyrite and narcasite $\left(\mathrm{FeS}_{2}\right)_{3}$ and $\mathrm{Fe}$ oxides (Mackorski, 1968; o'Gorman, and Walker, 1972; Griffin et al., 1980). Many other minerals are present locally or in trace amounts (Table 1). The bulk composition is usually dominated by quartz and aluminosilicates containing varylng proportions of $\mathrm{Fe}, \mathrm{Ca}$ and $\mathrm{Mg}$ and lesser amounts of $\mathrm{K}$ and $\mathrm{Na}$. The Eastern and Midwestern coals tend to have higher pyrite (and therefore Fe) contents, and the Western coals tend to contain higher than average $\mathrm{Ca}$ and $\mathrm{Mg}$ carbonates. The minerals occur in the coal as lsolated small grains, as thin layers and nodules enclosed by coal, as fracture fillings, and as separate beds of shale, sandstone, and sometimes limestone within and overlying the coal.

During burning, gasification, and liquefaction, the mineral composition is commonly modifled. Sillcates and oxides stable at higher temperatures are formed (feldspar, Fe-bearing silicate, magnetite, wollastonite, mullite). The pyrite breaks down to $\mathrm{Fe}$ oxides (hematite, $\mathrm{Fe}_{2} \mathrm{O}_{3}$, or goeth1te, FeOOH), FeS (pyrrhot1te or trollite) or Fe sulfate, and the $\mathrm{Ca}$, $\mathrm{Mg}$ and Fe carbonates decompose to oxides and sulfates. In some processes, the material partly melts to form glassy material or slag. Some constituents (e.g., Hg, As) are lost in volatila form, and other nonvolatile constituents 


\section{Table 1}

Important Minerals Occurring in Coal

(modifled after A. Davis, Penn. State Unlv., personal comunication)

\section{Clays}

Kaolinite $\mathrm{Al}_{2} \mathrm{SI}_{2} \mathrm{O}_{5}(\mathrm{OH})_{4}$

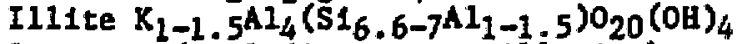

Smectite (including montmorilionite)

$\left.\mathrm{X}^{*} 0.33(\mathrm{A1}, \mathrm{Mg}, \mathrm{Fe})_{2-3}(\mathrm{S1}, \mathrm{A1}) 4_{10} \mathrm{O}_{10 \mathrm{OH}}\right)_{2}$

(*-exchangesble $\mathrm{Na}^{7}, \mathrm{~K}^{+}, \mathrm{Ca}^{27}$, etc.)

Mixed layer fllite-montmoriliond"?

Chlorite (Mg-Fe-Al silicate)

\section{Sulfides}

Pyrite FeS 2

Marcasite Fes 2

Sphalerite $(z \mathrm{n}, \mathrm{Fe}) \mathrm{s}$

Galena PbS

Chalcopyrite $\mathrm{CuFeS}_{2}$

\section{S111ca}

Quartz $\mathrm{SIO}_{2}$

Chalcedony $\mathrm{SiO}_{2}$

\section{Carbonates}
Calcite $\mathrm{CaCO}_{3}$
Dolomite CaMg $\left(\mathrm{CO}_{3}\right)_{2}$
S1dertte $\mathrm{FeCO}_{3}$
Ankerite $\mathrm{Ca}(\mathrm{Mg}, \mathrm{Fe})\left(\mathrm{CO}_{3}\right)_{2}$

\section{Sulfates}
Barite $\mathrm{BaSO}_{4}$
Gypsum $\mathrm{CaSO}_{4} \cdot 2 \mathrm{H}_{2} \mathrm{O}$
Jarosite $\mathrm{KFe}_{3}\left(\mathrm{SO}_{4}\right)_{2}(\mathrm{CI})_{6}$

Oxides

Hematite $\mathrm{Fe}_{2} \mathrm{O}_{3}$

Goethite $\mathrm{FeO}(\mathrm{OH})$

Phosphates

Apatite $3 \mathrm{Ca}_{3}\left(\mathrm{PO}_{4}\right)_{2} \cdot \mathrm{CaF}_{2}$

Others (usually minor to trace)

Feldspar $\mathrm{KAlS}_{3} \mathrm{O}_{8}$, $\mathrm{NaAlS1} \mathrm{O}_{8}, \mathrm{CaAl}_{2} \mathrm{Sl}_{2} \mathrm{O}_{8}$

Mica $\mathrm{KAl}_{3} \mathrm{Si}_{3} \mathrm{O}_{10}(\mathrm{OH})_{2}, \mathrm{~K}(\mathrm{Mg}, \mathrm{Fe})_{3} \mathrm{AlSi} \mathrm{i}_{3} \mathrm{O}_{10}(\mathrm{OH})_{2}$

Rutile $\mathrm{TiO}_{2}$

Anatase $\mathrm{TIO}_{2}$

$\mathrm{ZIrcOn} \mathrm{ZrStO}_{4}$

Tourmaline $\mathrm{Na}(\mathrm{Mg}, \mathrm{Fe}, \mathrm{Al})_{3} \mathrm{Al}_{6} \mathrm{SI}_{6} \mathrm{O}_{18}(\mathrm{BO})_{3}(\mathrm{OH}, \mathrm{F})_{4}$

Chlorifes

Nitrates 
formerly occurring in organic form in the coal are liberated as oxides and other compounds.

Physically, the wastes vary fron alcroscopic fly as? particles through slag to large boulder-size pleces of overburden at a strip oine. The strength also varies fron soft plastic clays and shales to hard brit"le sandstone or slag.

Coal Preparation Wate. Over three billion tons of coal cleaning wastes have accumulated in the U.S. and the current levels have exceeded 100 million tons per year. Nearly one third of the mined sal is discarded as refuse after physical cleaning. The refuse generally $r$ ntains waste coal, slate, carbonaceous and pyritic shales, pyrite, clay, and other impurities assoclated with a coal seam. Currently, most of the preparation plants dewater the fine refuse and dispose of it along wh coarse refuse in landf11ls or i'tsposal ponds.

The types of contaminants generated from coal cleanling waste at the landfill are suspended solids, dissolved solfds, metal fons, ecidity, and organic compounds. Leachates from coal preparatior refuse are varfable, in composition and volume, depending on the ras coal from thich they are derived as well as the amount of infiltzating zalnfall and other environmental factors. Because of the enrichment of many heavy metals in soals and the fact that many of the highily toxic metals such as mercury and lead are generally associated wh the mineral fraction, leachate from the refuse 1o commonly high in metal 1ons. In particular, acld leachates tend to have high contents of heavy metals beckuse most of these elements are relatively soluble in acid. The less comon neutral-tomalkaline leachates may be enriched in $\mathrm{S} 1, \mathrm{Ag}, \mathrm{B}$, and other elements forming oxyanions.

Coal Combustion Waste. Fly ash and hottom ash are Iesldues generated from conventional coal-fired power plante. Ash (1norganic materials) present in the inftial coal feedstock remalns as a solid waste. Chemically, this material may vary on a regional basis depending on the coal feedztock that 18 used.

Fly ash, the dominent waste materlal from many coal-fired electric power plants, varies widely in trace and major element content and in pH of leachates; these are a function of the coal source and the specific combustion temperature. However, typical fly ash is highly enriched (10x average solls) in $B, H B, S e, S r$, and $T e$ and significantly enriched ( $3 x$ average soils) In $\mathrm{Ag}, \mathrm{As}, \mathrm{Ba}, \mathrm{Cd}, \mathrm{Co}, \mathrm{Cr}, \mathrm{Cu}, \mathrm{Mo}, \mathrm{N}, \mathrm{Pb}, \mathrm{N}, \mathrm{Zn}$, and, in some cases, U (Furr et al., 1976; Dudas, 1981, unpub1lshed data). Generally, fly ashes produced from combustion of Western subbltuminous and 11gr:tic coals have higher than average boron content and produce leachates of alkaline pH. Ashes from combustion of Eastern and Mldwestern bituminous and subbituminous coals are generally higher in $S$, wore enriched in trace elenents such as As, $\mathrm{Cd}, \mathrm{Co}, \mathrm{Cr}, \mathrm{Pb}, \mathrm{Sb}$, and $\mathrm{Zn}$, and produce actdic leachates. Mineralogically, fiy ash consists of glassy spheres of ferro- and aluminosilicate composition $\left(\sim 60-90^{\circ}\right.$ wt. 7$)$ wth lesser quantities of quartz $\left(\mathrm{SIO}_{2}\right)$, mullite $\left(3 \mathrm{Al}_{2} \mathrm{O}_{3} \cdot 2 \mathrm{~S}^{\circ} \mathrm{O}_{2}\right)$, hematite $\left(\mathrm{Fe}_{2} \mathrm{O}_{3}\right)$, and magnetite $\left(\mathrm{Fe}_{2} \mathrm{O}_{4}\right)$ (Adriano et ai.., 1980; Wangen and Wewerka, DOE, ER-0131). Gypsum $\left(\mathrm{CaSO}_{4} \cdot 2 \mathrm{H}_{2} \mathrm{O}\right)$ and 
anhydrite $\left(\mathrm{CaSO}_{4}\right)$ are also commonly found, but nostiy in fly ashes frod Hestern U.S. coals. The ash and slag residues remalaing in the fire box. collectively referred to as bottom ash, are the other residues generated in a coal-fired power plant; these are generally less enrlched in trace element3. Residual organic carbon may also exist and fused aromatic compounds have been detected. When contacted with subsurface water, fly ash may produce leachates wth high ph, elevated levels of soluble salts, and sowe trace elements, Including B, Mo, Se, and Pb (Straughan et al., 197B; Dudas, 1981).

Coal Converaion Weste. The primary wastes produced by coal conversion processes include co.al cleaning residues and a mineral ash or slag remainiug after direct gasification of coal, or, in the case of liquefaction, from the gasification of the mineral residue or vacuun bottons. As with coal combustion, these wastes are subject to signiflicant varlability in chemical composition reflecting coal feedstock. Additional wastes produced in limited quantities in coal conversion include coaI gasification char (resldual carbon remaining after incomplete conversion), wastewater treatment sludge, spent catalysts, and still bottom and tar slusges.

Gasification mastes can vary significantiy with the specific processes ut1lized and are generally termed ashes or slag depending on the temperature reached during processing. Ashes, produced malnly by fluldized- and fixed-. bed gasifiers, contain a secondary ninaral asgemblage consisting of high temperature arystaliine silicates (mullite, Fe $2+-s 11$ icate), quartz, feldspars, and variety of 1ron oxides Buch as henatite, goethite, and magnetite (Griffin et al., 1980). These meterials way be fine-grained ashes or partially klinkered aggregateb. Slag is produced at higher temperatures by entralned-bed and some fluldized- and fixed-bed gasiflers and arises from the melting of coal minerals and their subsequent solidification upon cooling. Slags are composed mainly of amorphous and some pertially crystalline $\mathrm{Fe}^{2+}-\mathrm{Al}$ silicates, with the proportions of glass vs crystals and size of crystals depending upon the cooling rate (Griffin et:1., 1980). The particle size distribution of jlags is usually sand size, but may vary slgnificantly depending on the e:tent of mechanical crushing and specific waste handling procedures used in I1sposal.

The major elements found in gasification residues are $\mathrm{S1}, \mathrm{Al}$, and Fe (each compristing greater than $10 \%$ of the residue), and wh lesser amounts of $\mathrm{K}, \mathrm{Ca}_{3} \mathrm{Mg}$, and $\mathrm{Na}$. The concentrations of some minor elements ( $\mathrm{B}$, $\mathrm{Ba}$, and $\mathrm{V})$, as well as those of $\mathrm{Cu}, \mathrm{NI}, \mathrm{Cr}, \mathrm{Pb}$, and $\mathrm{Zn}$, can be quite high and exceed leveis found In most soil materlals (Griffin et al., 1980). The concentration and chemical form of $S$ may be quite varlable in gasifler slag 0.5 to 17) depending upon $S$ content 1 il the coal feedstock as well as the conversion process. Reduced $S$ forms have been detected in the gasification residues. A wide range of aromatic and allphatic hydrocarbons in low concentration have been detected in gaslficaclon (Francis and Wobber, 1982).

Laboratory leaching studies with selected gasifier ashes and siags produced mildly basic $(\mathrm{pH} 8.0-9.0)$ or ecldic $(\langle 4.0-6.5)$ leachates with varylgg quantitias of soluble salts $\left(\mathrm{Ca}, \mathrm{SO}_{4}\right)$. Some minor clements (e.g., B) trace metals (e.g., $\mathrm{Cd}, \mathrm{Pb}, \mathrm{Al}, \mathrm{Fe}, \mathrm{AB}, \mathrm{Mn}$. Mo, $\mathrm{Sb}$ ), and macrolons ( $\mathrm{K}, \mathrm{NH}_{4}$ ), 
occasionally exceed water quality criteria (Griffin et all., 1980). Those wastes producling acid leachates generally contain higher levels of metals and sulfate (Francis and Nobber, 1982), possibly resulting from the formation of soluble ferric sulfates or the oxidation of residual reduced sulfur remaining after conversion.

\section{B. Uranium MIII Tailengs}

The particle size of uranium mill tallings is typically 60 to 707 sand $(50-200(1 \mu \mathrm{m}), 15$ to $20 \%$ silt $(2-50 \mu \mathrm{m})$, and 15 to $20 \%$ clay $(<2 \mu \mathrm{m})$. The mincralogy 1s strongly dependent on the parent ors bedy, but quartz, feldspars, and phyllosilicates are ubiquitous ln tallings from sandstonc uranturn ore deposits, the predomituant ore type currently belng mined in the United States. Chemically, the mill tallings are composed of maj21 elements $S 1$, $\mathrm{Al}, \mathrm{Fe}, \mathrm{Hg}, \mathrm{Ca}, \mathrm{Na}, \mathrm{K}$, and $\mathrm{Mn}$ accompanled by varylng amounts of $\mathrm{Z} \pi$, $\mathrm{NI}, \mathrm{Mo}$, $\mathrm{Cr}, \mathrm{V}$, and Se and other trace elements. In particular, Se, Mo, $v$, and $\mathbb{U}$ may be found in elevated levels Jver average sandstone and soll concentrations. Approximately 107 of the criginal uranim and almost all members of the urantum decay series in tie original ore $\left(238_{\mathrm{V}}, 234 \mathrm{U}, 230_{\mathrm{Th}}, 226_{\mathrm{B}}\right.$ ? and $210_{\mathrm{Pb}}$ are retained in the tallings in amounts much higher than 1 n normal solis. In addition to these enrlched ore constituents, high levels of inorganic species are present in spent leach solutions discharged frcm mills: $\mathrm{SO}_{4}{ }^{2-}$ from acld leach solutions, $\mathrm{Na}^{+}$from cartonate leach solutions, $\mathrm{Cl}^{-}$ from sodium chlorate oxidant, and $\mathrm{NH}_{4}{ }^{+}$used in yellowcake precipitatics. Further, many major and atnor elements, For example, Fe and Nin, are dissolved during acid leachling of uranlum ore. Organic chemicals such as tert:iary amines, alkylphosphoric acids, isodecanol, and kerosene (as a carrler) used in solvent extraction clrcults are also found in mill liquors disposed of in tailing ponds.

\section{TMPORTANT CHARACTERISTICS OF MODEL SUBSTRATE}

In selecting a substrate material for experiments, it is important to consider that 1t meets the objectives of the study, the kinds of effects this material might have on the outcome of experiments, and the range of characteristics that $\mathbf{m}^{*} \mathrm{ght}$ be found $1 \mathrm{n}$ nature. The characteristics of the substrate that are expected to be 1mportant to microblal processes in the mobllization of trace metals are summarized as follows:

a. Characteristics influencing pti and major element content of aqueous solutions in contact wh the substrate.

b. Characteristics Influencing the oxidation state of aqueous solutions.

c. Surface area and other surface propertles of particles comprising the waste or substrate, and the resulting adsorption ano catalysis of reactions.

d. Abundance and form of toxic elements.

e. Size, shar?, and strength of particles comprising the substrate. 
A. Major Elenent Concentration and pH of Aqueous Solutions

The mobility of nost cations 18 affected by $\mathrm{pH}$ and 1s any situations by other diseolved constituents that form insoluble conpounds or soluble complexes wth contaninants. In gene.al, cations are wot wobile in acid solutions and anions tend to be more mobile in basic solution.

Acld pH: The najor waste constituent causing acid pH values is pyrite (or warcasite) and 1ts oxidation products. In the presence of oxygenated water, pyrite and narcastite oxidize in the following sequence of reactions:

$$
\begin{aligned}
& \mathrm{FeS}_{2}+7 / 2 \mathrm{O}_{2}+\mathrm{H}_{2} \mathrm{O}-\mathrm{Fe}^{2+}+2 \mathrm{SO}_{4}{ }^{2-}+2 \mathrm{H}^{+} ; \\
& \mathrm{Fe}^{2+}+1 / 4 \mathrm{O}_{2}+\mathrm{H}^{+}=\mathrm{Fe}^{3+}+1 / 2 \mathrm{H}_{2} \mathrm{O}, \\
& \mathrm{Fe}^{3+}+3 \mathrm{H}_{2} \mathrm{O}=\mathrm{Fe}(\mathrm{OH})_{3}+3 \mathrm{H}^{+} .
\end{aligned}
$$

If $\mathrm{Fe}^{3+}$ concentration Is aigaificent ( $\mathrm{pH}$ belos about 4.5 ), Fe ${ }^{3+}$ acts $3 \mathrm{c}$ the oxidant of pyrite rather than $\mathrm{O}_{2}$ :

$$
\mathrm{FeS}_{2}+14 \mathrm{Fe}^{3+}+8 \mathrm{H}_{2} \mathrm{O}=15 \mathrm{Fe}^{2+}+2 \mathrm{SO}_{4}^{2-}+16 \mathrm{H}^{+} \text {. }
$$

The $\mathrm{Fe}^{3+}$ is regenerated by catalysis of Reaction (2) by Thiobacillus ferrooxidans, greatly accelerating the reaction. In addition to production of $\mathrm{SO}_{4}{ }^{2}-$ by Reaction (i), less oxidized sulfur opecies may be formed $\left(\mathrm{SO}_{3}{ }^{2-}\right.$. $\mathrm{S}_{2} \mathrm{O}_{3}{ }^{2-}, \mathrm{s}^{0}$, polysulfides, etc.). These apecies eventuaily transform to $\mathrm{SO}_{4}{ }^{2-}$, but may be involved in catalyzing or inhibiting the reactions.

The pH commonly reaches 2 to 3 during oxidation of pyritic material and occasionally goes to 1.5. Values of $p H$ between 3 and 6 are observed in less pyritic materials in oxygen-depleted Fe ${ }^{2+}$-rich solutions thich have not yet indergone Reaction (3), or in solutions neutralized by reaction with other minerals. Under some conditions, ferrfic oulfate or jarosite (Table 1) may precipltate. These species are most stable at $\mathrm{pH}$ of 2 to 3 . The $\mathrm{Fe}(\mathrm{OH})_{3} \mathrm{gradually}$ dehydrates and recrystallizes to hematite or goethite.

The acid produced in Reactions (1), (3), and (4) may be neutralized by reactions wth carbonates and other minerals to form solutions enriched in $\mathrm{Ca}, \mathrm{Mg}, \mathrm{K}, \mathrm{Na}$, etc.:

$$
\begin{aligned}
& \mathrm{CaCO}_{3}+2 \mathrm{H}^{+}=\mathrm{Ca}^{2+}+\mathrm{H}_{2} \mathrm{O}+\mathrm{CO}_{2}, \\
& 2 \mathrm{KAlSI}_{3} \mathrm{O}_{3} \text { (feldspar) }+2 \mathrm{H}^{+}+\mathrm{H}_{2} \mathrm{O}=\mathrm{Al}_{2} \mathrm{SI}_{2} \mathrm{O}_{5}(\mathrm{OH})_{4}+4 \mathrm{SiO}_{2}+2 \mathrm{~K}^{+} .
\end{aligned}
$$

Kelatively high concentrations of various cations may be achieved in this manner. Reaction (5) is apld, but reactions like (6) with aluminosilicates tend to be much slower. The breakdown of most minerals by the acid solutions liberates many trace elements (Rb, $\mathrm{Sr}, \mathrm{Ba}, \mathrm{V}, \mathrm{Cr}, \mathrm{Mn}, \mathrm{Ni}, \mathrm{Cu}, \mathrm{Zn}, \mathrm{Ga}$, $\mathrm{Ge}, \mathrm{As}, \mathrm{Se}$, Mo, Ag, Cd, Sb, Hg, Tl, U, and others) as well as the major constituents ( $\mathrm{K}, \mathrm{Na}, \mathrm{Ca}, \mathrm{Mg}, \mathrm{Al}, \mathrm{Si}, \mathrm{Fe}, \mathrm{S}$ ). Under sone conditions, sulfates and oxides, such as gypsum, barite, or rutile, may precipitate. 
In 11quefaction wastes pyrrhotite is connonly present rather than pyrite. The initial breakdown of pyrrhotite produces no acid:

$$
\mathrm{FeS}+2 \mathrm{O}_{2}=\mathrm{Fe}^{2+}+\mathrm{SO}_{4}{ }^{2-} \text {. }
$$

However, this reaction 1 followed by (2) and (3), which do produce actd.

Other sulfides containing Fe behave like pyrrhotite, but nearly all other common sulfiles oxidize whthout forning acid.

If highly acid condition are produced by pyrite oxidation or similar processes, sone Al ay be dissolved from aluminosilicates. This Al can later precipitste as $A l(\mathrm{OH})_{3}$ or sinilar phases, releasing acid in a reaction analogous to (3). However, the initial acid sas produced by pyrite oxidation, and the disavived Al lor soluble Al minerals such as $\left.\mathrm{Al}_{2}\left(\mathrm{SO}_{4}\right)_{3}\right]$ may be considered stored acidity.

Alkaline pH: At the other extreme of high $\mathrm{pH}$, the most common control 1s probably the formation of alkaline-earth oxides and hydroxides by decomposition of carbonates during gasification or ilquefaction

$$
\begin{aligned}
& \mathrm{CaCO}_{3}=\mathrm{CaO}+\mathrm{CO}_{2}(\mathrm{~g}), \\
& \mathrm{CaO}+\mathrm{H}_{2} \mathrm{O}=\mathrm{Ca}(\mathrm{OH})_{2}-\mathrm{Ca}^{2+}+2 \mathrm{OH}^{-} .
\end{aligned}
$$

Th1s reaction and the analogous one for $\mathrm{Mg}$ can produce $\mathrm{pH}$ values as high as 11 to 12. As an apparent example of this process, a 11quefaction maste and a Lurgi ash tested by Griffin et al. (1980) produced $\mathrm{pH}$ values of 11.31 and 11.05 when slurried with water. Another posslble cause of high pH might be the presence of soluble amonia compounds formed in liquefaction or gasif1cation.

Neutral pH: In the Intermediate pH region, carbonate minerals in combination with dissolved carbonate or gaseous $\mathrm{CO}_{2}$ are the most important $\mathrm{pH}$ controls. This system has been discussed by Garrels and Christ (1965). In a solution exposed to a flxed $\mathrm{P}_{\mathrm{CO}_{2}}$, such as $10^{-3.5}$ atm in open atr, the dissolution reaction for calcite $\mathrm{Cs}^{2}$

$$
\begin{aligned}
& \mathrm{CaCO}_{3}+\mathrm{CO}_{2}(\mathrm{~g})+\mathrm{H}_{2} \mathrm{O}=\mathrm{Ca}^{2+}+2 \mathrm{HCO}_{3}^{-}, \\
& \mathrm{k}_{10}=\frac{{ }^{a} \mathrm{Ca}^{2+}+{ }^{2} \mathrm{HCO}_{3}^{-},}{\mathrm{P}_{\mathrm{CO}_{2}}}
\end{aligned}
$$

where a Indicates chemical activity of the solute and $K$ is an equilibrium constant. The system must also satisfy the various carbonate equilibrla so that

$$
\mathrm{CC}_{2}+\mathrm{H}_{2} \mathrm{O}=\mathrm{H}^{+}+\mathrm{HCO}_{3}^{-} \text {. }
$$

If $\mathrm{Ca}^{2+}$ is derived only by dissolution of calcite, the equations can be solved to give $\mathrm{pH}=8.4$. At higher values of $\mathrm{PCO}_{2}$, as alght be found in the subsurface, $\mathrm{pH}$ values are lower. If calctte or other carbonates are not present, Eq. (11) defines a $\mathrm{pH}$ near 5.5 for atmospheric $\mathrm{P}_{\mathrm{CO}_{2}}$. In general, 
these reactions are relatively rapid for calcite, and slover for other carbonates.

Other minerals in the energy waste may affect $\mathrm{pH}$ values at a much slower rate than the reactions discusised above. For example, for aluninosilfcate aterials, reactions like (6) may tend to buffer $p$ H. Such reactants could include glass formed on meling of the ash aterials. In general, it appears that $\mathrm{AJ}$-rich residues will terd to form silghtly acid solutions on breakdown, and $\mathrm{Ca}, \mathrm{Mg}-$, and Na-rlch residues will have an alkaline reaction.

In summary, wastes wh soluble ferric minisals will tend to produce acfd leachates, westes with high temperature decomposition products of carbonates will produce alkaline leachates, Fe-sulfides exposed to oxygenated environments wil produce actd leachates, and other nineralogies will generally produce leachates of intermediate $\mathrm{pH}$. Some of the last will react only very slowly and their $\mathrm{pH}$ effects may be overwhelmed by more rapid reactlons if waters percolate through the waste at a significant rate.

\section{B. Oxfdation State of Ieachates}

The main reducing constituents in wates include sulf Ides, ferrous iron compounds, and ozganic nutter. As prevlously described, the oxidation of sulfides consumes oxygen and can lead to reducing conditions, ammonly on the stability boundary of $\mathrm{Fe}^{2+}$ with Fe-oxide (Klelnmann et al., 1981), or perhaps in some cases on the $\mathrm{Fe}^{2+}$-pyrite boundary (or Fe $\mathrm{F}^{2+}$-pyrrhotite boundary, if it is the sulfide present) (Figures 1-3). The Fe ${ }^{2+}$ may be complexed

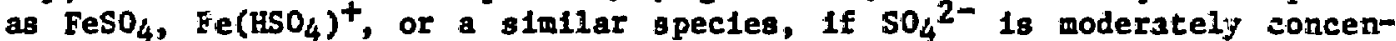
trated. Attainment of these low redox values usually Involves the setivity of Thiobacillus or other bacteria that catalyze pyrite dissolution.

Organic compounds in bituminous and anthracite coal probably oxidize only very slowly in oxygenated environments, because the more reactive conponents have been consumed or lost in the original process of forming the coal. Some organtc matter in lignite might oxidize rapldiy enougli to consume $\mathrm{O}_{2}$. However, experiments on the reactivity of these materials are needed to confirm shether these materials can be utilized by heterotrophic bacteria. In general, coal is probably not a very potent reductant because most of the rapidly reacting functional gro:lp 3 were probably consumed or destroyed by bacteria active during coal fornation and subsequent elevated temperatures in the geologic past.

The organic compounds formed during liquefaction and possibly during gagification may oxidize relatively rapidly, either by themselves or throwgh bacterial action, to consume $\mathrm{O}_{2}$ and other oxidants and thereby create a reducing environment.

Ferroug compounds such as ferrous swlfates, ferruus silicates (clays, chlorite, pyroxene, glasses), and ferrous oxldes (magnetite) may be soluble and reactive enough to create a reducing enviroment. The sulfates are readily soluble (though an aid solution would dissolve them more rapidly). 


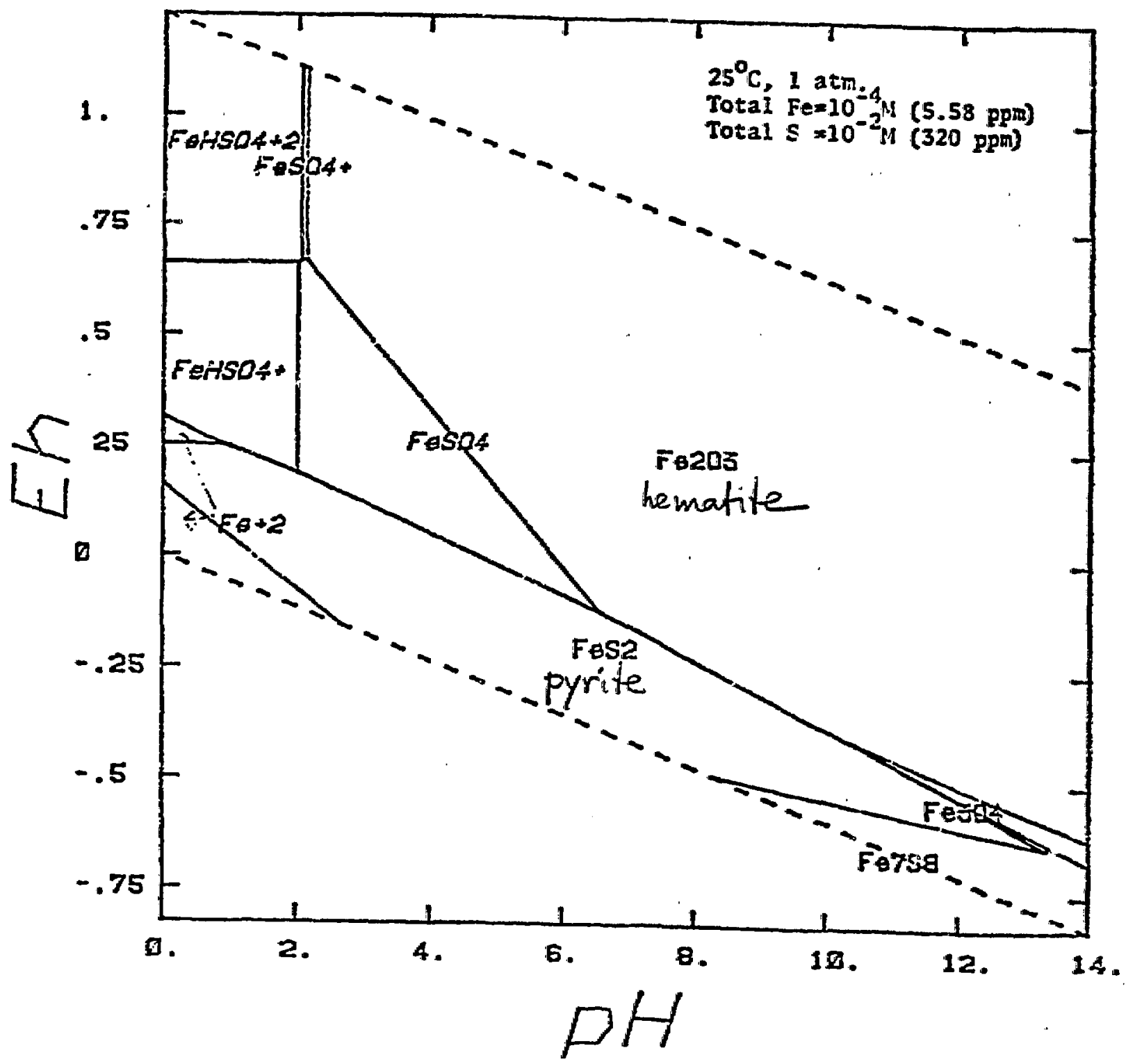

Figure 1. Eh-pH diagram for the system Fe-5-0-H. Species wiltien in vertical letters are solids, and species written in slanted letters are aqueous species. $\mathrm{Fe}_{2} \mathrm{O}_{3}$ is hematite, Fey $\mathrm{O}_{4}$ is magnetite, $\mathrm{FeS}_{2}$ is pyrite, and $\mathrm{Fe}_{7} \mathrm{~S}_{8}$ is pyrrhotite. Data largely from Parker et al. (1976) and Langmuir (1969), comp1led by H. L. Barne3, D. Langwuir, and comorkers. 


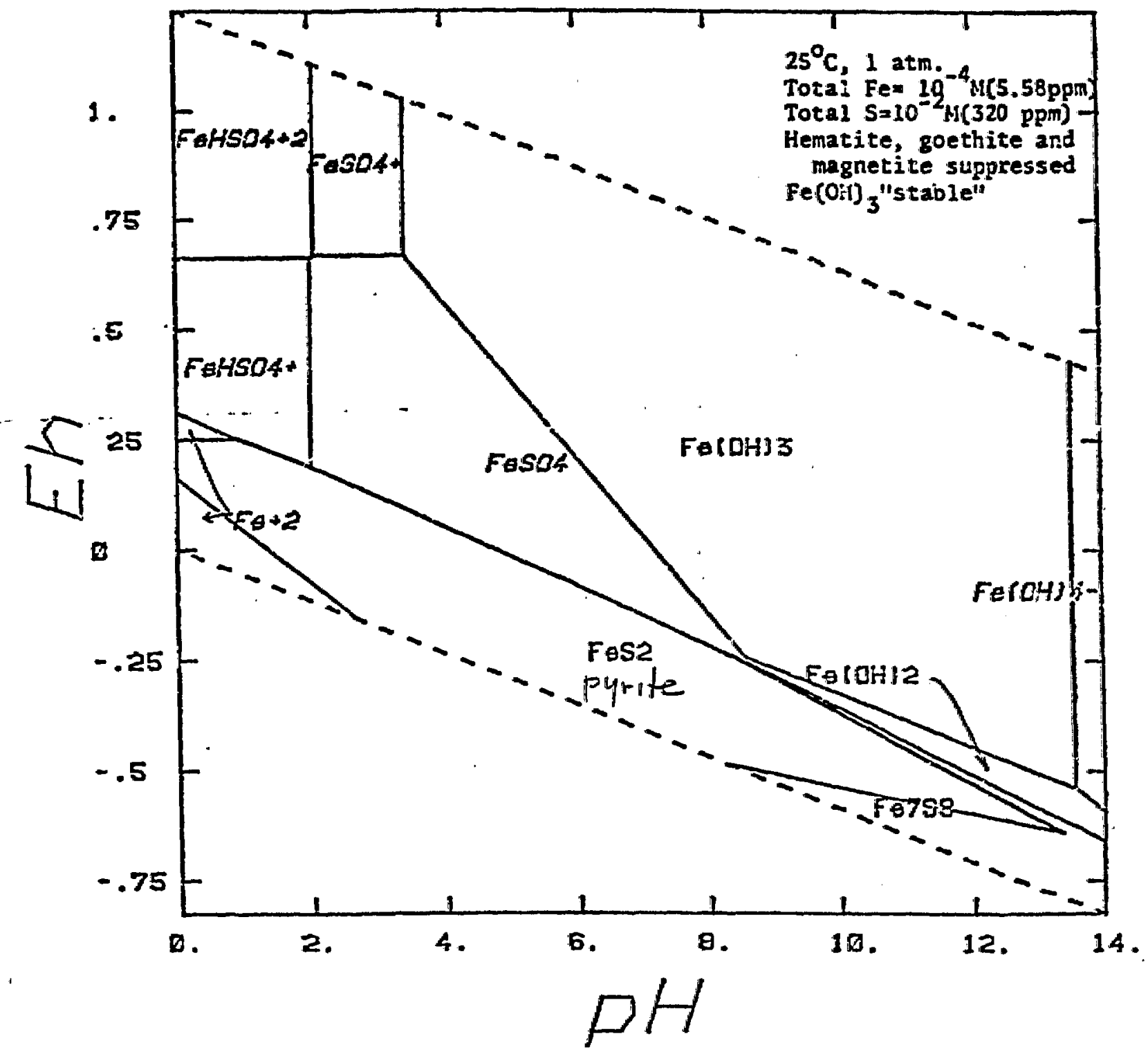

Figure 2. Eh-pH diagram for the system Fe-S-OH with hematite, goethite, and magnetite suppressed so that amorphous $\mathrm{Fe}(\mathrm{OH})_{3}$ is the atable phase. Symbols same as in Figure 1. Note the increased extent of the field of $\mathrm{Fe}$ (II) soluble as $\mathrm{FeSO}_{4}$. 


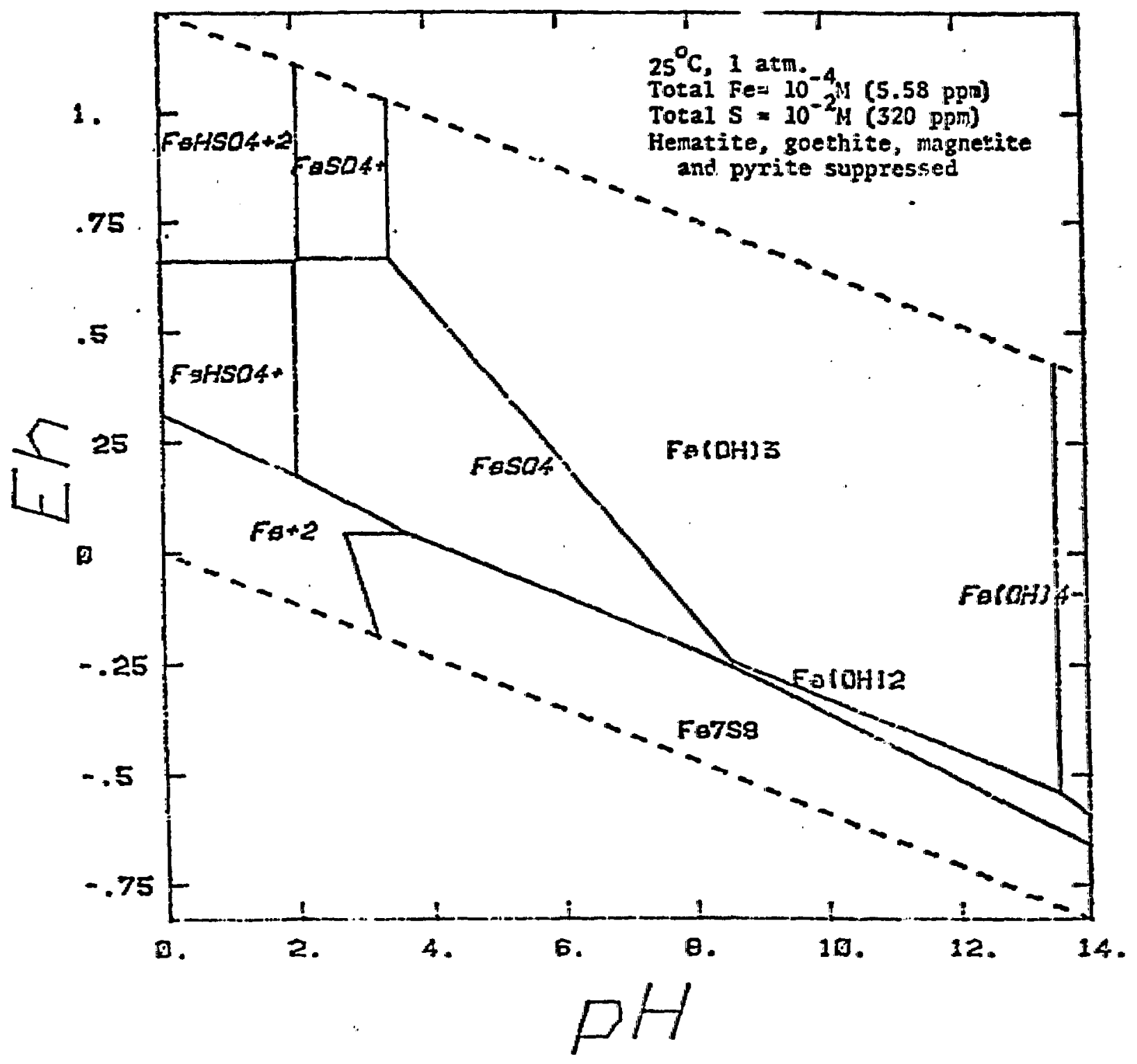

Figure 3. Eh-pH diagram for the system Fe-s-OH with hematite, goethite, magnetite and pyrite suppressed so that pyrrhotite is the major reduced sulfur phase. Symbols same as in Figure 1. 
Possible oxidizlng agents in the wastes include ferric oxides [hematite, goethite, Fe(OH) 3 ], ferric sulfate, and possibly anganese oxides $\left(\mathrm{MnO}_{2}, \mathrm{Mn}_{2} \mathrm{O}_{3}\right)$, and any ferric iron lil silicates and glasses. The Fe(III) and oxides would react relatively rapidiy, especially if fine grained. Oxidation states along or near the $\mathrm{Pe}(\mathrm{OH}) 3-\mathrm{Fe}^{2+}$ boundary would be expected if $\mathrm{Fe}^{3+}$ compounds are present: (FIgures 2 and 3 ). The sillcates and glasses would react eiowly, in the absence of acid, and probably would generally include both $\mathrm{Fe}$ (III) and $\mathrm{Fe}$ (II) $80 \mathrm{highly}$ oxidizing conditions would not be 11kely.

In sumary, the moat likely phases controllins the oxidation state include Fe-sulfides, ferric oxides, and non-coal organic compounds.

\section{Surface Properties of Particles In Substrate}

The reaction of solids with leachates 18 enhanced by a large surface area, and the adsorption of dissolved constituents and the catalysis of reactions are strongly dependent on the surface area of the solid naterial. For example, hematite $\left(\mathrm{Fe}_{2} \mathrm{O}_{3}\right)$ wth a grain size of $1 \mathrm{~mm}$ tould adsorb negligible amounts of trace elements like $\mathrm{Pb}$, but fine-grained henatite in particles of 1 Hin or less wight immobilize all lead from solution by adsorption on 1ts surface, which has $10^{9}$ times the area of a similar mass of $1 \mathrm{~mm}$ grains (Jenne, 1968). For these reasons, the physical otate (particle and crystal size) of energy waste materials is cruclal in determining the character of leachates.

Fe-oxides are very good adsorbents for a wide varlety of cations and anions (Jenne, 1968). Experiments show that colloldal and fine-grained Feoxides strongly adsorb transition metal cations ( $\mathrm{Cu}, \mathrm{Pb}, \mathrm{Zn}, \mathrm{Cd}, \mathrm{MI}, \mathrm{Co}, \mathrm{Ag}$ ) at $\mathrm{pH}$ values greater than about 5 to 6 (Benjamin and Leckie, 1981; Balestrleri and Murray, 1982). High concentrations of competing adsorbent: may inhibit adsorpcion, as can strong complexing, but the presence of finegrained Fe-oxides will generaliy minimize the content of transition metal cations in ieachates. The Fe-oxides also bind strongly to $\mathrm{AsO}_{4}{ }^{2-}$, $\mathrm{SeO}_{4}{ }^{2-}$, $\mathrm{SeO}_{3}{ }^{2-}, \mathrm{MoO}_{4}{ }^{2-}, \mathrm{NO}_{2}{ }^{2+}$, and similar specles, especlally under acld conditions (Harrison and Berkheiser, 1982). If the Fe-oxides are coarse grained, and well-crystalline, this adsorption will be decreased. Typlcally, the Feoxides coat other particles, for example, clays, and the area of the Feoxide surface is therefore maximized by fine particle size of the overall material. Freshly precipitated Fe oxides are generally far more reactive than aged precipitates.

Mn-oxides are generally even more effective adsorbents than Fe-oxides, in part, because they can strongly adsorb cations to more acid pH values than Fe oxides. In addition, the Mn-oxides are effective in catalyzing some oxidation-reduction reactions.

Similar effects are known for ton exchange on clays, and for adsorption on partly decayed organic matter of solls and peats. Arthracite and bituminous coals generally do not have surface areas large enough to be slgnificantly adsorbent, but lignites may. The chars and similar materials forned in gasification and liquefaction could have large surface areas and 
reactivities. Glasses and vapor condensates of the type found in fly ash are expected to have large surface areas and may be relatively reactive.

In sumnry, finely divided Fe-oxides, organic matter, glasses, and fine grain size, In general, will tend to enhance reactivity and adsorption, and must be controlled in a nodel waste form.

\section{Abundance and Chemical-Minerdlogical Form of Trace Elements}

For study of the nobilization and dispersion of toxic trace elenents from wastes, the ausudance of these elements in the waste is obviously critical, as is the chenical form in which the elements occur. Fur example, in a study of 56 coal ashes from various coal fields of the U.S., Pb ranged from 20 to $1500 \mathrm{ppm}$, and $\mathrm{Hg}$ in 10 coals ranged from 0.11 to $13.3 \mathrm{ppm}$ (O'Gorman and Walker, 1972). Many other transition metai trace elements have concentration ranges of several orders of magnitude. Regional differences in coals are also documented (Gluskoter et al., 1977). A waste with low concentrations of an element is likely to produce only minor environmental problens for this element, and wastes with high concentrations have a high potential for contamination.

The chenical-mineralogical form of the element can be at least as 1mportant as the total concentration. As noted previousiy, wastes contain some very soluble minerals and others that react slowly. Trace elements iacorporated in or co-precipitated of th soluble minerals wil be rapidy released to solution, whareas trace elements in relatively stable minerals rill generally be released very slouly, as the host mineral breaks down. For example, it seens likely that $A s$ and $S e$ in oxidized vastes may occur as arsenate, arsentte, selenate, and selentte anions incorporated in Fe or $\mathrm{Ca}$ sulfates and be readily relessad to solution. Most of the $\mathrm{Zn}, \mathrm{Cd}$, and $\mathrm{Pb}$ in coals containing high amounte of these elements probably occur in readily oxidized and soluble $\mathrm{ZnS}$ and PbS. In fly ash, a considerabie proportion of many trace elements is apparently loosely bonded to particle surfaces, and is thereby readily avallable. In contrast, high concentrations of $\mathrm{Cr}$ night occur in relatively stable minerais such as magnetite or pyroxene [( $\left.\mathrm{Fe}, \mathrm{Mg}) \mathrm{SlO}_{3}\right]$. The readily 30 luble constituents are wuch wore reactive and potentially toxic in both short-term experiments and large-scale waste disposal.

\section{E. Particle Size, Shape, and Strength}

Theae characteristics are related to the surface area, but seem distinctive enough to justify separation in considering a model maste medium. The porosity and perreability of the waste are dependent on particle size and strength. A coarse $(>1 \mathrm{~mm}$ ) waste composed of fraguents strong enough to support overlying material will pack with a relatively high proportion of open space tith large openings, and consequently wil tend to drain readily and be alr-filled if above the water table. In contrast, a fine-grained materlal like fly ash, especially if it contains a wide range of grain sizes, will have very small pore spaces, and water will tend to be held in the pores by caplliary forces. Flow through this waste wil be slow, and air will probably not have easy access by convection. 
Similarly, if the fragments or particles are weak or plastic, the fragments in the bottom of the waste pile will crumble or deform to decrease or eliminate the pore space. Also, silt- and clay-size particles will tend to expose more surface to solution attack.

\section{SELECTION OF A REPRESENTATIVE SUBSTRATE FOR MICROB IOLOGICAL RESEARCH}

A model or a representative mediug should possess the anjor physical and chenical properties comon to all energy residues and contain trar. metals in their natural and nodified (after conbustion, conversion, etc.) forms. Microblal transformations of metals in 3uch tiedium can be tudied under controlled conditions. If necessary, appropriate addition of organic and/or Inorganic compounds can be achleved to study the effect on microbial dissolution of trace aetals.

The major types of residues from current or projected utilization of coal are conl cleaning waste, fly ash, and coal gasification ash and wastes from uranium mining and milling. Although there are several major physical and chemical characteristics comon to energy-related solid wastes (Table 2), each of these waste materials has a unique set of physical and chemical characteristics which seem to rejresent absolute opposites. For example, high organic matter content versus low organic natter content, dominance of Iron sulfides and sulfates as opposed to a doninance of iron crides, fine grained wth hlgh surface area $\mathrm{r}$ irsus low surface area, acid versus alkaline pH, and a high content of glasses as opposed to low glass content.

The analyses of Griffin et al. (1980) suggest that ash from gasification tends to be partly cxidized (Table 3, presence of goethite and hematite, as well as some magnetite), whereas Ilquefaction wastes tend to be more reducing (pyrrhotite, pyrite present, no goethite or hematite). The use of a gasification waste would thus allow research on reducing conditions brought about by the activities of anaernbic bacteria. The oxidized forms of metals present in gasification wise under appropriate conditions (temperature, pH, moisture, carbon source, alternate electron acceptors, etc.) would undergo reduction due to anaerobic microblal activity. In contrast, the reduced components present in the 11quefaction waste may be oxidized by microorganisms under aerobic conditlons, and the oxidized components in the leachate may be reduced by the anaerobic microblal action in subsurface environments. The mobility of the wetal under these conditions is dependent upon the metal form (speclation) and solubility.

The very fine particle size and large stiface area of fly ash probably make this material less suitable for use as a model substrate than other materlals. Some fly ashes apparently contain relatively high concentrations of adsorbed elements or soluble condensates.

Given all these variables, it does not seem that a single material can be used as a model substrate for microblological experimentation. Alternatively, it might be desirable to mix different kinds of waste materials in combination so that they reflect all the characteristics 11sted above. Once this model substrate is created and characterized physically and shemically, 
Table 2

Physical/Chemical Characteristics Comnon to Energy-Relatri Solid Wastes (Zachara et al., 1982)

\begin{tabular}{|c|c|c|c|c|c|c|c|c|c|}
\hline & \multicolumn{4}{|c|}{ Coal } & \multicolumn{3}{|c|}{ OII Shale } & \multicolumn{2}{|c|}{ Nuclear } \\
\hline & \multirow{2}{*}{$\begin{array}{l}\text { Conbustion } \\
\text { Ely Ash }\end{array}$} & \multirow{2}{*}{ 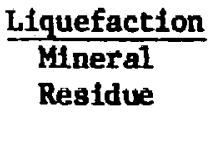 } & \multicolumn{2}{|c|}{ Gasification } & \multicolumn{2}{|c|}{ Western } & \multirow{2}{*}{ Eastern } & \multicolumn{2}{|c|}{ Uranius Mil1 Tallings } \\
\hline & & & $\begin{array}{l}\text { Bottan } \\
\text { Ash or Slas }\end{array}$ & Fly Ash & $\begin{array}{l}\text { Lon T } \\
\text { Retorted } \\
\text { Shale }\end{array}$ & $\begin{array}{l}\text { High T } \\
\text { Retorted } \\
\text { Shale }\end{array}$ & & $\begin{array}{l}\text { Acid } \\
\text { Leach }\end{array}$ & $\begin{array}{l}\text { Carbonate } \\
\text { Leach }\end{array}$ \\
\hline \multicolumn{10}{|l|}{ Solid Characteristics } \\
\hline Organic Regldues & + & $\mathbf{x}$ & + & + & $\mathbf{x}$ & $\mathbf{0}$ & $\mathbf{x}$ & $\mathbf{0}$ & 0 \\
\hline Sulfides & & $\mathrm{x}$ & + & + & $\mathbf{x}$ & & $\mathbf{x}$ & + & 0 \\
\hline Carbonates & $\mathbf{x}^{\mathbf{b}}$ & & & & $\mathrm{x}$ & $x^{b}$ & & + & \\
\hline Amorphic Oxides & $\mathbf{x}$ & & $\mathbf{x}$ & & $\mathrm{x}$ & $\mathbf{x}$ & & & \\
\hline $\begin{array}{l}\text { High Tenperature } \\
\text { Silfcates }\end{array}$ & $\mathbf{x}$ & & $\dot{\mathbf{x}}$ & & & $\mathbf{x}$ & & & \\
\hline Trace Elements & $\mathbf{x}$ & $x$ & $\mathbf{x}$ & + & $x$ & $\mathbf{x}$ & $\mathbf{x}$ & $\mathbf{x}$ & $\mathbf{x}$ \\
\hline Fine Texture & $\mathbf{x}$ & $\mathbf{x}$ & te & + & $\bar{x}$ & $\mathbf{x}$ & $\mathbf{x}$ & $\mathbf{x}$ & $\mathbf{x}$ \\
\hline $\begin{array}{c}\text { Coarse Texture } \\
(50 \%>2 \mathrm{un})\end{array}$ & & & $\mathbf{x}$ & & $\mathbf{x}$ & $x$ & $\mathbf{x}$ & $\mathbf{x}$ & $\mathbf{x}$ \\
\hline \multicolumn{10}{|c|}{ Leachate Characterlatics } \\
\hline $\begin{array}{l}\text { Hifh Salts } \\
\text { (TDS }>2000) \mathrm{ng} / 1\end{array}$ & $x$ & + & + & & $\mathbf{x}$ & 0 & + & $\mathbf{x}$ & $\mathbf{x}$ \\
\hline Alkalinity & $\overline{\mathbf{x}}$ & + & + & & $\mathbf{x}$ & & & & $\mathbf{X}$ \\
\hline Trace Elements & $\mathbf{x}$ & + & + & + & $\bar{x}$ & $\mathbf{0}$ & $\mathbf{x}$ & $\mathbf{x}$ & $\mathbf{X}$ \\
\hline Reduced S & & $0^{\mathrm{d} .}$ & & 0 & $\mathbf{x}$ & 0 & $\mathbf{0}$ & & \\
\hline High pH (>9) & $\mathbf{x}$ & + & + & & $\bar{x}$ & 0 & + & & $\mathbf{x}$ \\
\hline Low pH $(<4)$ & + & $o^{d}$ & + & $\sigma^{\mathbf{d}}$ & & $\mathbf{x}$ & $\mathbf{x}$ & & \\
\hline $\begin{array}{l}\text { Organics } \\
\text { Other }\end{array}$ & & $\mathbf{x}$ & & & $\mathbf{x}$ & $\mathbf{0}$ & 0 & 0 & $\mathrm{x}$ \\
\hline
\end{tabular}
$X$ = Observed in most analyses.
a. Coal and Hquefaction residues.
$+\equiv$ Occasionally observed.
b. Secondacy formation after
c. Depends or taste handing
0 - Data not available in open literature. pyrolysis.
d. Hith tiwe. 
Table 3

Mineral Composition of Coals and Coal Solfd hastes (Giffin et al., 1980)

\begin{tabular}{|c|c|c|c|c|c|c|c|c|c|c|c|c|c|c|c|}
\hline & $\begin{array}{l}\text { Rooe- } \\
\text { bud }\end{array}$ & $\begin{array}{l}\text { Nb. } 6 \\
\text { (mashed) }\end{array}$ & $\begin{array}{l}\text { Nb. } 5 \\
\text { (washed) }\end{array}$ & $\begin{array}{l}\text { Fines } \\
\text { (slurty) }\end{array}$ & $\begin{array}{c}\text { Refuse } \\
\text { (higtr-s } \\
\text { gob) }\end{array}$ & $\begin{array}{r}\text { Refuse } \\
(10 w-s \\
g 0 b)\end{array}$ & $\begin{array}{l}\text { Hedium- } \\
\text { temper- } \\
\text { ature } \\
\text { char }\end{array}$ & $\begin{array}{l}\text { High } \\
\text { temper- } \\
\text { ature } \\
\text { char }\end{array}$ & $\underset{\operatorname{cosl}^{\mathrm{H}} \mathrm{R}}{\mathrm{H}}$ & $\begin{array}{c}\text { Lurgl } \\
\text { ash } \\
\text { (1b.6 } \\
\text { coal) }\end{array}$ & $\begin{array}{c}\text { Lrgi } \\
\text { ash } \\
\text { (N..5 } \\
\text { conl) }\end{array}$ & $\begin{array}{l}\text { Irgd } \\
\text { ach } \\
\text { (Rose- } \\
\text { bud) }\end{array}$ & $\begin{array}{l}\text { Fly } \\
\text { ash }\end{array}$ & $\underset{\text { residue }}{\text { SFC }}$ & $\begin{array}{l}\text { Hater } \\
\text { quenched } \\
\text { slag }\end{array}$ \\
\hline \multicolumn{16}{|c|}{ Nonferro minerals } \\
\hline Sphalerite & $=$ & $\mathbf{x}$ & $\mathbf{x}$ & - & - & $\mathbf{x}$ & - & - & - & - & - & - & - & - & - \\
\hline Quartz & $x^{*}$ & $\mathbf{x}$ & $\mathbf{x}$ & $\mathbf{x}$ & $\mathrm{x}$ & $\mathrm{x}$ & $x$ & $\mathbf{x}$ & $\mathbf{X}$ & $x$ & $\mathbf{x}$ & $\mathbf{x}$ & $x$ & $\mathbf{x}$ & - \\
\hline Calcite & $\mathrm{x}$ & $\mathbf{x}$ & $\mathbf{x}$ & $\mathbf{x}$ & $\mathbf{x}$ & $\mathbf{x}$ & $\mathbf{x}$ & $\rightarrow$ & $\mathbf{x}$ & - & - & $=$ & - & - & - \\
\hline Dolante & $\mathbf{x}$ & $x$ & $x$ & - & - & 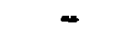 & - & - & - & $=$ & - & $x$ & - & - & - \\
\hline Antydrite & $\mathbf{x}$ & $\mathbf{x}$ & $\mathrm{x}$ & $\mathbf{x}$ & - & - & $\mathbf{X}$ & - & - & - & - & - & $\mathbf{x}$ & - & - \\
\hline Bascinite & $\mathbf{x}$ & - & - & $\mathrm{x}$ & - & - & - & - & - & - & - & - & - & - & - \\
\hline Gypar & $\mathbf{x}$ & - & - & $=$ & - & - & - & - & - & - & - & - & - & - & - \\
\hline Kaolinite & $\mathbf{x}$ & $\mathbf{x}$ & $\mathrm{x}$ & $\mathbf{X}$ & $\mathbf{x}$ & $\mathbf{X}$ & - & - & $\mathbf{x}$ & - & - & - & - & $\mathbf{x}$ & - \\
\hline Bxpendable clay & $\mathbf{x}$ & $\mathbf{x}$ & $x$ & - & - & - & - & - & $\mathbf{x}$ & - & - & - & - & $\mathrm{x}$ & - \\
\hline Feldspar & - & - & - & $\mathbf{x}$ & $\mathbf{x}$ & $\mathbf{x}$ & $\mathbf{x}$ & - & - & $\mathbf{x}$ & $\mathbf{x}$ & $\mathbf{x}$ & - & - & - \\
\hline Wllastantte & - & - & - & $=$ & - & - & - & - & SEyth & - & $=$ & $=$ & - & - & - \\
\hline \multicolumn{16}{|c|}{ Ferro afnerals } \\
\hline Pyrtte & $x *$ & $\mathbf{M K}^{*}$ & $M$ & $M$ & $\mathbf{M K}$ & $\mathrm{x}$ & $\mathbf{M x}$ & $\mathbf{M x}$ & - & - & - & - & - & - & - \\
\hline Pyrchotite & $\approx$ & - & - & - & - & - & $\mathbf{x}$ & $\mathbf{w}$ & $\mathbf{m}$ & - & $\cdots$ & - & - & $\mathrm{m}$ & - \\
\hline riutef & $\mathbf{x}$ & $\mathrm{x}$ & $\operatorname{Mx}$ & $\mathbf{x}$ & $\mathbf{M x}$ & 15 & $\mathrm{kx}$ & $x^{\prime \prime}$ & - & - & - & - & - & - & $=$ \\
\hline Mullitet & - & - & - & - & - & $=$ & - & - & - & $\mathbf{m x}$ & $\mathbf{M}$ & $\mathbf{K K}$ & - & $=$ & - \\
\hline Melinterite & $x$ & - & - & - & - & - & - & - & $=$ & $=$ & - & - & $=$ & $\Rightarrow$ & $=$ \\
\hline Fet2 allicate & - & - & - & $=$ & - & - & $\infty$ & 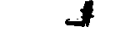 & $=$ & $\mathbf{H}$ & $\mathbf{H}$ & $\mathbf{M}$ & $\mathbf{M}$ & - & $\mathbf{H}$ \\
\hline Hanatite & - & - & $=$ & - & - & - & - & - & - & $\mathbf{x}$ & Hx & $\mathbf{s x}$ & Mx & - & - \\
\hline Coethite & $\mathbf{x}$ & - & - & - & $=$ & $=$ & - & - & - & $\mathbf{M}$ & $\mathbf{M}$ & $\mathbf{M}$ & $\mathbf{M}$ & - & - \\
\hline Mgratite & - & - & - & - & - & - & - & 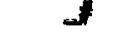 & - & $\mathbf{M}$ & $\mathbf{H}$ & $\mathbf{M}$ & $\mathbf{H}$ & - & $=$ \\
\hline $\begin{array}{l}\text { Hytrated ferrous } \\
\text { suilfate }\end{array}$ & $=$ & - & $2 x^{5}$ & - & $\mathbf{m} \times$ & - & $\operatorname{Mx}$ & $\mathbf{N X}$ & $\mathbf{N x}$ & - & - & - & - & $5 x$ & - \\
\hline Ferrouv carbanate & $=$ & - & $\Rightarrow$ & - & - & M & - & $=$ & 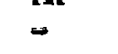 & $=$ & $\Rightarrow$ & - & $=$ & $=$ & - \\
\hline
\end{tabular}

* X-tay analyses.

* Schaning electron atcroecope.

$\dagger x$-ray diffraction camot distingulsh between valence states of tron.

+ M-vosibaker analyolo.

$\$$ Sihytrove:

- Spinel group hercyntte. 
1t night be utilized by several researchers and the results correlated. However, in practice the disposal of a combination of all these waste materials is very unilkely. Research on such a mixed medium would provide some general information on bacterial activities, but the elucidation of basic scientific inforation on the types of reactions and the controlling factors would be more difflcult becauge of the mixture of waste properties. These deficiencies obviously make the use of a mixed model waste also undesirisle.

A preferred approach to nicrobiological experimentation is to utilize several materials or substrates wich reflect uniquely different character1stics of the range of expected environments. For example, a substrate with a high, pH and low organic carbon and a substrete with a low pH and high organic carbon could be selected. Each end member materlal would be characterized Individually and subjected to microbla? research (Tables 4 to 6). In addition to experiments on end-members, varlous ratios of the different substrates could be mixed, duplicating the range of expected environments, and subjected to the same inicroblal studies as were previously conducted on the individual substrates. The data collected from the individual substrates could be used to formulate hypotheses on the microbial activity of unknown systems.

For inftial studies, the following three substrates are selected, using the end-member concept to examine most of the problems in microblologlcal and related effects:

1. A coal-cleaning waste with hlgh content of pyrite and trace elements;

2. A gasification waste that is at least partly oxidized; and

3. Peat with h1gh organic carbon ani low levels of trace elements.

These three substrates are chosen on the basis of physical and chemical characteristics as weli as avallability. The gasifick =ion waste represents an end-menber in oxidation state and is avallable from pilot gasiflcation Flants.

The pyritlc coal-cleaning wate, in addition to being a type of wate produced in signiflcant mounts by some current and proposed processes, would be relatively reducing chemically and rould produce considerable acld on oxidation, thereby providing a range of reducing-neutral to oxidizing acld conditions under appropriate physical conditions, as in a large lowpermeablitty plle or colum with slowly flowing oxidizing water. A large sample of such a waste wes collected from a nafor coal-cleaning plant near Clearfield, Pennsylvania. Th1s waste contalins high concentration of the toxic elenents $\mathrm{As}, \mathrm{Cd}, \mathrm{Pb}, \mathrm{N}$, and $\mathrm{Hg}$ (Table 7), as mell as in pyrite. Because of natural oxidation of pyrite, the coal-cleaning waste and the mixture wil be stored in sealed contalners, possibly in an inert gas atmosphere, to avold changes in character wth tive, 1.e., developnent of various soluble sulfates by oxidation of the pyrite. Research is examining the behavior of these phases and the toxic elements in a range of conditions 


\section{Table 4}

Microblal Dissolution of Toxic Metals in Anaeroblc Erviroments

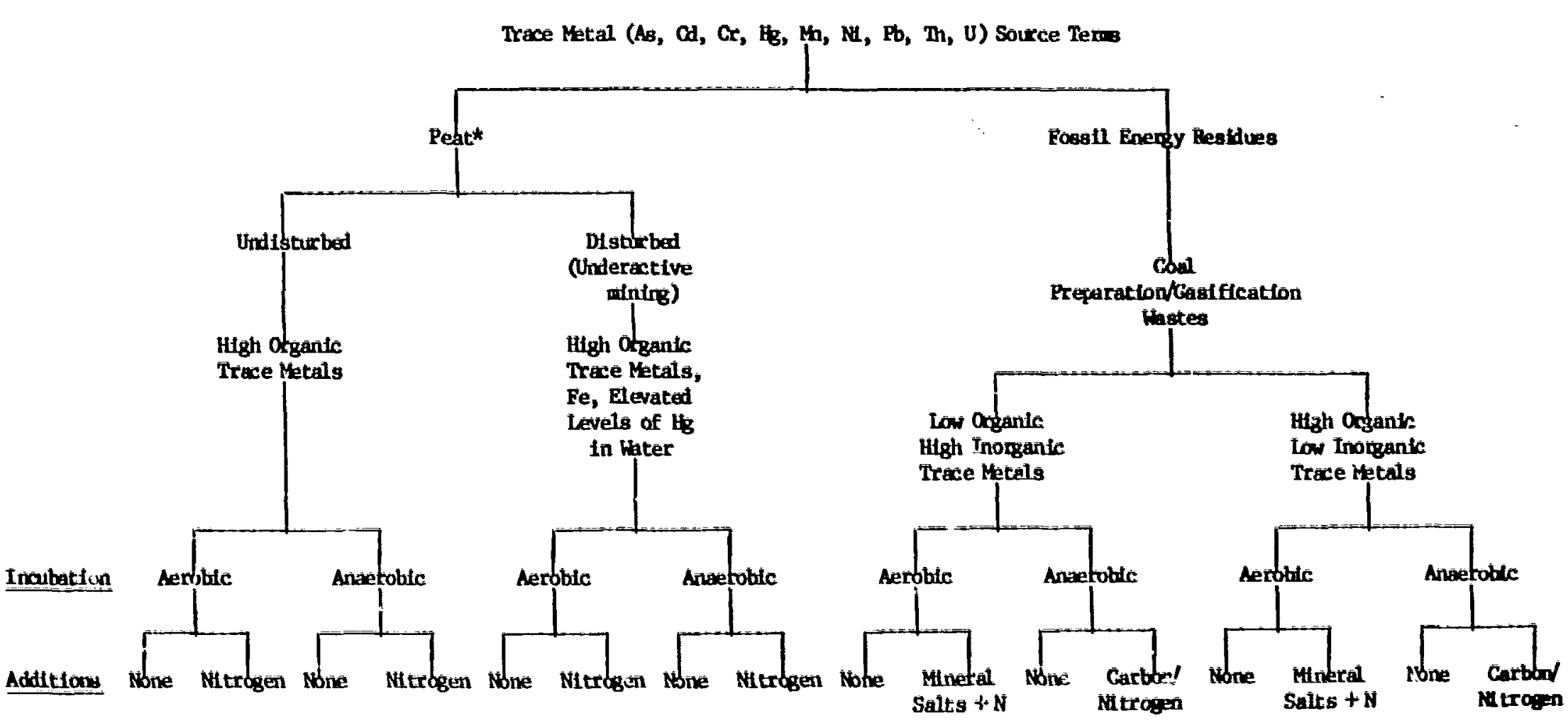

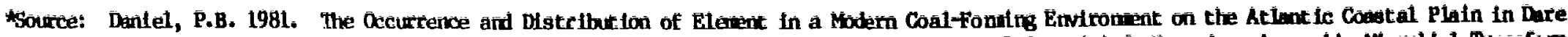

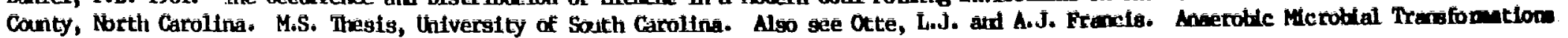
of Trace Metals and Onganics in Peat: Fleld Site Guaracterizicics. 
Table 5

Metal Forms for Use In Laboratory Experiments*

\begin{tabular}{|c|c|c|}
\hline Name & Formula & $\begin{array}{c}\text { Relevance for } \\
\text { Study }\end{array}$ \\
\hline Arsenopyrite & (FeAs)S & 1 \\
\hline $\begin{array}{l}\text { Sphalerite } \\
\text { Greepochite } \\
\text { Cadnium Oxide } \\
\text { Cadmlum }\end{array}$ & $\begin{array}{l}\text { (ZnCd)s } \\
\text { Cds } \\
\text { Cdo } \\
\mathrm{Cd}^{\circ}\end{array}$ & $\begin{array}{l}1 \\
2 \\
3\end{array}$ \\
\hline $\begin{array}{l}\text { Galena } \\
\text { Lead Oxide } \\
\text { Lead }\end{array}$ & $\begin{array}{l}\mathrm{PbS} \\
\mathrm{PbO} \\
\mathrm{Pb}\end{array}$ & $\begin{array}{l}1 \\
2 \\
3\end{array}$ \\
\hline $\begin{array}{l}\text { Milerite } \\
\text { Pentlandite } \\
\text { Nickel OxIde } \\
\text { Nickel }\end{array}$ & $\begin{array}{l}\text { N1S } \\
\text { (NIFe)S } \\
N 10 \\
N i^{\circ}\end{array}$ & $\begin{array}{l}1 \\
1 \\
2 \\
3\end{array}$ \\
\hline
\end{tabular}

* Final choice will depend upon avallability in form needed for experiment to examine microbial dissolution and mechanism involved.

1. Natural form of element - present in peat, coal beneficiation waste.

2. Oxidized form - pregent in coal combustion and conversion residues.

3. Reduced form - present in peat, coal conversion wastes, particularly coal liquefaction wastes. 
Table 6

Effect of Environuental Varlables on Selected Trace

Metal Dissolution from Representative Waste Medium

\begin{tabular}{|c|c|c|}
\hline Temperature & \multicolumn{2}{|c|}{$12-15^{\circ} \mathrm{C}$} \\
\hline Molsture & \multicolumn{2}{|c|}{ Saturated, unsaturated } \\
\hline pHE & \multicolumn{2}{|c|}{$\begin{array}{l}\text { Neutral }(\sim 7) \text {, acidic }(\sim 2.0-5.0) \text {, and } \\
\text { alkaline }(\sim B)\end{array}$} \\
\hline Oxygen & \multicolumn{2}{|c|}{$\begin{array}{l}\text { Anaeroblc, partially anaerobic, aerobic } \\
\text { and aerobic/anaerobic/aeroblc }\end{array}$} \\
\hline $\begin{array}{l}\text { Alternate electron acceptors } \\
\text { under anaerobic conditions }\end{array}$ & $\begin{array}{l}\text { (1) } \\
\text { (i1) } \\
\text { (ii1) } \\
\text { (iv) } \\
\text { (v) } \\
\text { (vi) }\end{array}$ & $\begin{array}{l}\text { Nitrate } \\
\text { Sulfate } \\
\text { Ferric oxides } \\
\text { Manganic oxides } \\
\text { Carbonate } \\
\text { Fermentation (energy ylelding) } \\
\text { oxidation-reduction reaction in } \\
\text { wich organic conpounds serve as } \\
\text { the final electron acceptors) }\end{array}$ \\
\hline
\end{tabular}


Table 7

Physical, Chemical and Blological Characterization of Coal Beneficiation Residues (Francis, A.J., C. Dodge and H.L. Qulnby, unpublished results).

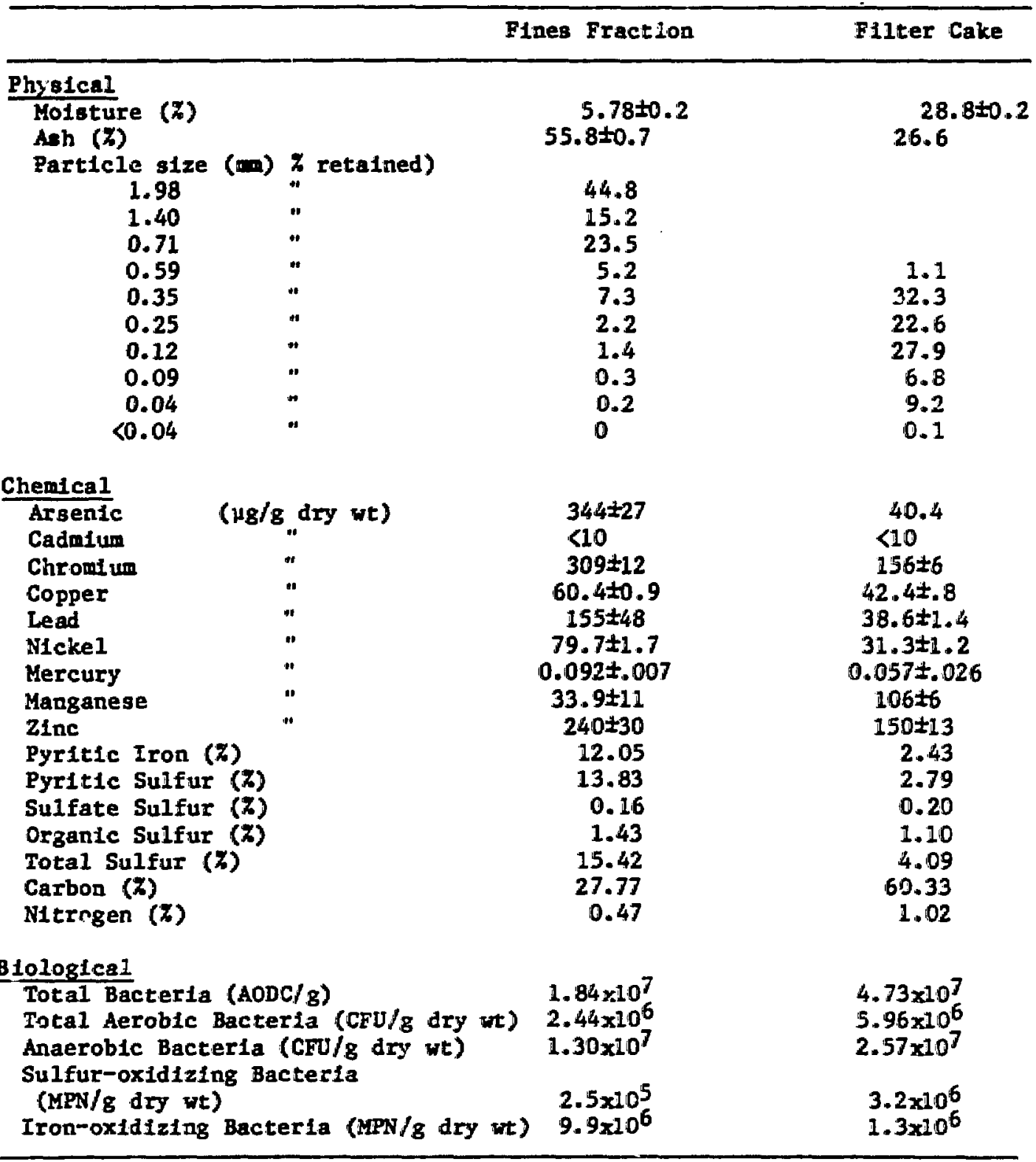

AODC-Acridine Orange Direct Counts

CFU --Colony Forming Units

MPN - Most Probable Number 
(Table 6), Including variable particle size, which can be varied by grinding, to exantine effects of perweablilty and surface area. The oxidation of the pyrite under aerobic conditions can produce ferric oxides that should be effectlve adsorbents for any trace elenents which can also serve as a source of trace netals for anserobic afcrobial dissolution under anoxic conditions.

A specific gasification waste has not yet been collected but represents an oxidized end-nember. In 1 ts natural state, it might be elther acid or basic, depending on whether the coal from which it was produced was rich in pyrite (oxidized to acid ferric salts) or In Ca and $\mathrm{Mg}$ carbonates (converted to basic $\mathrm{Mg}$ or a Ca hydroxides). A waste with little of either of these constitients 111 be sought and the pli uLII be adjusted by added acid or base during experiments. The toxic trace elements in this waste would probsbly be in readily soluble oxidized forms, in glassy or fine crystalline silicate material and adsorbed on surfaces. The sillcates would break dom gradually to release trace elements more slowly than the pyrite in the coal-cleaning waste. Fe-oxides in small amounts might be forned to act as adsorbents, but would be less abundant than in the coal waste. Organic carbon from ccal gasification would constitute the main reductant, and would probably be ralatively inert in the absence of bacterlal activity. The surface area for reaction could again be varled by sleving or grinding. The physical strength of particles might remain higher than the coal-cieaning waste because no major phase would be rapldly decomposing as pyrite would in the coal-cleanfing wate.

The coal-cleaning wate is readily avallable from many locations in the eastern U.S. Gasification whete appears to be avallable from a number of test sites.

\section{SUMANRY}

The key characteristics of several substrates generated due to energyrelated activities were reviewed in order to select a nodel substrate for anaerobic microbiological research in subsurface environments. These include trace metal content, form (natural and modifled), organic carbon content and $\mathrm{pH}$. Model substrates high in trace metals and Iow In organic carbon (coal benefication and coal gasification residues); low in trace metals and high in organic carbon (peat); and several insoluble forms of pure metals and minerals were selected for microblological research. These substrates will be used in experiments to determine the role ard significance of anaerobic microbial processes in the dissolution and mobilization of trace metals under those conditions expected in subsurface environments. The basic information generated from this gtudy should be useful to the transport of trace metals in subsurface and anoxic environments. 


\section{REPERENCES}

Adriano, D.C., A.I. Page, A.A. Elseewl, A.C. Chang, and J. Straughan, 1980, Utilization and disposal of $f J y$ ash and other coal residues in terreatrial ecosystens: A revlew: J. Environ. Qual. 9, 333-42.

Balestrier 1, L.S. and Murray, J.W., 1982, The adsorption of $\mathrm{Cu}, \mathrm{Fb}, \mathrm{Zn}$ and Cd on goethite from najor Ion seawacer: Geocinin. Cosmochim. Acta 46, 1253-67.

Benjamin, M.M. and Leckle, J.0., 1981, Multiple-site adsorption of Cd, Cu, $\mathrm{Zn}$ and $\mathrm{Pb}$ on anorphous iron oxyhydroxide: $\mathrm{J}$. Collold Interface Sc1. $83,410-17$.

Dudas, M.J., 1981, Long-term leachability of selected elements from f1y ash: Environ. Sc1. Technol. 15, 840-43.

Francis, C.F. and F.J. Wobber, 1982, Status of Health and Environmental Research Relative to Solid Wastes fron Coal Conversion: U.S. DOE/NBB-0008/1.

Furr, A.K., T.F. Parkinson, W.H. Gutenmann, and D.J. L1st, 1976, Muitlelement uptake by vegetables and millet grown in pots on fly ash amended Boll: J. Agric. Food Chem. 26, 357-59.

Garre1s, R.M., and Christ, C.L., 1965, SolutLons, minerals and equ1libria: liarper and Row, New York, p. 74-92.

Gluskoter, H.J., Ruch, R.R., Miller, H.G., Cahill, R.A., Dreher, G.B. and Kuhn, J.K., 1977, Trace elements in coal: Occurrence and distribution: I11. State Geolog. Surv. Circ. 499, 154 pp.

Griffin, R.A., Schuller, R.M., Suloway, J.J., Shinp, N.F., Chllderes, W.F. and Sh1ley, R.H., 1980, Chemical and biological characterization of leachates from coal solid wastes: Environ. Geol. Notes 89, III. State Geol. Surv., 99 pp.

Harrison, J.B. and Berkhelser, V.E., 1982, Anfon 1nteractions with freshly prepared hydrous iron oxides: Clays: Clay Miner., 30, 97-10.2.

Jenne, E.A., 1968, Controls on N, Fe, Co, Ni, $\mathrm{Cu}$ and $\mathrm{Zn}$ concentrations in soils and water: The significant role of $\mathrm{Mn}$ and Fe oxides: Adv. Chem. Ser. No. 73, p. 337-88.

Kleinmann, R.R., Crerar, D.A., and Pacel11, R.R., 1981, Biogeochemistry of acid mine dratnage and a method to control acld formation: Min. Eng. (N.Y.) 33, 300-304.

Mackowsk1, M-Th., 1968, Mineral matter in coal: In Coal and Coal-Bearing Strata, edited by Murch1son and Westoll, 011ver and Boyd, Edinburgh, p. 309-321. 
$0^{\prime}$ Gorman, J.V and Walker, P.I Jr., 1972, Mineral mater and trace elements in U.S. coals: Research and Dev. Rept 61, Interim Rept. 2, office of Coal Research, U.S. Dept. of Interlor $184 \mathrm{pP}$.

Straughan, I., A.A. Elseew1 and A.I. Page, 1978, Mobilization of selected trace elements in residues from coal combustion with special reference to fly ash in Trace Substances in Environmental Health - XII, edited by D.D. Hemphi11, Univ, of Missour1, Columbia, MO, P. 389-402.

Wangen, L.E., and E.M. Wewerke, Solld vaster from energy-producing technologies. Solld wastes from conl converolon and conventional coal combustion processes: DOE/ER-0132.

Hobber, F.J., 1283, Subsurface transport program: Geochem1cal, hydrolog1cal and blological cycling of energy residuals: DOE/ER $-0156 / 1$.

Zachara, J.M., R.E. W11dung, and F.J. Hobber, 1982, Subsurface transport with emphasis on hydrology: Research needs: DOE/ER-0177 